TEACHING : Jurnal Inovasi Keguruan dan IImu Pendidikan

Vol. 1. No. 3 September 2021 e-ISSN : 2775-7188 | p-ISSN : 2775-717X

\title{
PEMBELAJARAN BERBASIS PROYEK BERSAMA PT. PESONA KHATULISTIWA NUSANTARA DENGAN METODE BLENDED LEARNING UNTUK MENINGKATKAN KEAKTIFAN PESERTA DIDIK DIMASA COVID-19
}

\author{
ASTRIA ZAITIA \\ SMKN 1 Tanjung Palas, Kab. Bulungan, Kalimantan Utara \\ Email : astria.zaitia@gmail.com
}

\begin{abstract}
ABSTRAK
Pembelajaran berbasis proyek dengan metode blended learning merupakan salah satu metode pembelajaran yang dapat meningkatkan keaktifan peserta didik selama masa pandemic Covid-19. Best Practice dilaksanakan pada semester Genap tahun ajaran 2020/2021 mulai bulan Januari sampai Juni 2021 . Tempat pelaksanaan Best Practice adalah SMKN 1 Tanjung Palas, Kec. Tanjung Palas, Kab.Bulungan Provinsi Kalimantan Utara. Subyek penelitian adalah kelas X ATPH 1 dan 2 dengan jumlah 47 orang. Sekolah berkesempatan menjalin kerjasama dengan IDUKA (PT. Pesona Khatulistiwa Nusantara) dalam hal peningkatan kualitas dan kinerja khususnya peserta didik pada komptensi keahlian Agribisnis Tanaman Pangan dan Hortikultura melalui pembelajaran berbasis proyek untuk program Pembibitan Kakao. Dalam pelaksanaannya, penulis menggunakan metode blended learning yaitu pembelajaran yang memadukan pembelajaran secara tatap muka dan daring. Best Practice ini menggambarkan tentang peningkatan keaktifan peserta didik selama mengikuti pembelajaran dengan metode blended learning. Ada 3 aspek pengamatan yang diharapkan mewakili dimensi keaktifan belajar peserta didik yaitu : 1. Prestasi belajar, 2. Kerjasama dalam kelompok, 3. Kehadiran/absensi peserta didik, baik dalam pembelajaran daring maupun luring/praktek. Kesimpulan Best Practice digambarkan dalam bentuk grafik dan tabel. Dapat disimpulkan bahwa keaktifan peserta didik berdasarkan prestasi belajar meningkat mulai dari KD.1 sampai dengan KD.5 sebesar $80,85 \%$ yaitu 38 orang aktif dan $87,23 \%$ yaitu 41 orang aktif bekerjasama dalam kelompok. Selanjutnya keaktifan peserta didik ditinjau dari aspek kehadiran dalam pembelajaran daring mengalami fluktuatif, sedangkan pada pembelajaran luring mengalami peningkatan sebesar 90,90\%.
\end{abstract}

Kata Kunci : Pembelajaran berbasis proyek, metode blended learning, keaktifan siswa, kerjasama dengan IDUKA

\section{PENDAHULUAN}

Sekolah Menengah Kejuruan (SMK) merupakan salah satu bentuk pendidikan formal yang menyelenggarakan pendidikan kejuruan pada jenjang pendidikan menengah. Salah satu tujuan pendidikan kejuruan yang tertuang dalam Undang-Undang Sistem Pendidikan Nasional (UU Sisdiknas) Nomor 20 tahun 2003 yaitu menyiapkan peserta didik yang profesional dalam bidang keahliannya dengan memiliki sikap ulet, gigih dalam berkompetensi dan beradaptasi di lingkungan kerja. Untuk mencapai tujuan tersebut, pemerintah menyelenggarakan model Pendidikan Sistem Ganda atau dual system, dimana sekolah menggandeng Institusi Pasangan IDUKA sebagai mitra, untuk memadukan secara sistematis dan sistemik program pendidikan di SMK dan program latihan di dunia kerja.

Pendidikan Sistem Ganda menurut Wolf dalam Astuti (2020), menyatakan bahwa kegiatan Pendidikan sistem ganda, sebagai : "two pleace of learning of equal value ang the same standard are combined together to form a system". Model PSG memiliki dua tempat kegiatan yaitu pembelajaran yang dilaksanakan di sekolah atau pembelajaran berbasis sekolah (school based learning) dan pembelajaran yang dilaksanakan di tempat bekerja (work based learning). Proses pembelajaran di sekolah dilakukan oleh guru di sekolah masing-masing, dan pendidikan di tempat bekerja oleh pembimbing di industri. Kondisi ini semakin berkembang, sehingga pembelajaran berbasis industri yang awalnya hanya dilaksanakan pada saat anak sedang di industri saat ini sudah dapat berkolaborasi sehingga instruktur dari industri dapat menjadi guru 


\section{TEACHING : Jurnal Inovasi Keguruan dan IImu Pendidikan Vol. 1. No. 3 September 2021 e-ISSN : 2775-7188 | p-ISSN : 2775-717X}

tamu dengan datang di SMK. Program pembelajaran dengan melibatkan industri, diharapkan peserta didik mampu menguasai aspek-aspek kompetensi yang menjadi tuntutan kurikulum industri dan peserta didik dapat mengenal lebih awal tentang dunia kerja.

Berdasarkan Peraturan Menteri Pendidikan Dan Kebudayaan No 22 tahun 2016 tentang Standar Proses Pendidikan Dasar dan Menengah, guru harus mampu mewujudkan proses pembelajaran secara interaktif, inspiratif, menyenangkan, menantang, memotivasi peserta didik untuk berpartisipasi aktif, serta memberikan ruang yang cukup bagi prakarsa kreativitas, dan kemandirian sesuai dengan bakat, minat, dan perkembangan fisik serta psikologis peserta didik. Salah satu model pembelajaran yang terpusat pada peserta didik yang dapat digunakan dalam pembelajaran adalah pembelajaran berbasis proyek (project based learning). Model pembelajaran ini menjadi salah satu rujukan pemilihan model pembelajaran dalam Kurikulum 2013. Pembelajaran berbasis proyek adalah model pembelajaran yang menggunakan proyek/kegiatan sebagai pembelajaran untuk mencapai kompetensi sikap, pengetahuan, dan keterampilan.

Namun saat ini pendidikan di Indonesia sedang mengalami salah satu permasalahan pada masa pandemic covid-19 semua pendidik melakukan kegiatan akademik dari rumah. Pendidik melakukan pembelajaran virtual atau online dalam melakukan pembelajaran. Mendikbud mengeluarkan petunjuk pembelajaran untuk tahun akademik 2020/2021 dalam menyikapi pandemi covid-19 (Marbun, 2020). Petunjuk pembelajaran yang dikeluarkan Mendikbud menitik beratkan guru menyajikan pembelajaran yang inovatif, kreatif , menyenangkan dan mudah dipahami sehingga peserta didik tidak merasa bosan melaksanakan kegiatan pembelajaran dari rumah. Guru dituntut dapat menggunakan aplikasi-aplikasi dalam menunjang kegiatan pembelajaran, diantaranya menggunakan google classroom, zoom, google meet dan platform yang menunjang dalam pembelajaran (Baalwi, 2020).

Pelaksanaan Pembelajaran Jarak Jauh (PJJ) tentunya tidak bisa lepas dari jaringan internet. Koneksi jaringan internet menjadi salah satu kendala yang dihadapi siswa yang tempat tinggalnya sulit untuk mengakses internet, apalagi siswa tersebut tempat tinggalnya di daerah pedesaan, terpencil dan tertinggal. Kalaupun ada yang menggunakan jaringan seluler terkadang jaringan yang tidak stabil, karena letak geografis yang masih jauh dari jangkauan sinyal seluler. Selain itu, tidak semua peserta didik memiliki gawai Android dan kuota internet yang bisa menunjang kegiatan pembelajaran. Permasalahan ini banyak terjadi pada peserrta didik yang mengikuti pembelajaran daring menyebabkan kurang optimal pelaksanaannya sehingga pada akhirnya berdampak pada kurangnya minat belajar peserta didik.

Pembelajaran SMK pembelajaran yang menitikberatkan pada pembelajaran praktek juga menjadi kendala. Peserta didik akan kesulitan ketika pelaksanaan pembelajaran dengan PJJ tanpa peserta didik praktek langsung. Keterampilan ini akan dimiliki peserta didik saat langsung praktek, melihat alat langsung proses keterampilan yang harus dikuasai. Penggunaan media pembelajaran dengan video (online) hanya dapat membantu memberi gambaran pada peserta didik bagaimana kondisi praktek dan keahlian apa saja yang seharusnya dikuasi oleh peserta didik. Sehingga pembelajaran online tentunya akan kurang bermakna tanpa sinergitas strategi dan metode pembelajaran yang tepat.

Berdasarkan hal ini perlu adanya pembelajaran yang efektif diterapkan terhadap peserta didik untuk meningkatkan kompetensi mereka. Sehingga pembelajaran berbasis proyek menjadi salah satu solusi. Pada awal tahun 2021 Kompetensi Keahlian Agribisnis Tanaman Pangan dan Hortikultura SMKN 1 Tanjung Palas bersama dengan IDUKA PT. Pesona Khatulistiwa Nusantara melalui program pembibitan Kakao melaksanakan pembelajaran berbasis proyek dengan menggunakan metode blended learning. Metode ini mengkombinasikan antara pembelajaran online dengan face-to-face (pembelajaran tatap muka). Peserta didik mendapatkan materi melalui pembelajaran daring kemudian melaksanakan praktek langsung dengan tetap mematuhi prokoler kesehatan. Peningkatan kompetensi peserta didik melalui pelaksanaan Pembelajaran berbasis Proyek pada kelas X, XI dan XII Agribisnis 
Tanaman Pangan dan Hortikuktura menjadi alternatif pembelajaran yang inovatif, kreatif serta dapat menumbuhkan budaya kerja industri di SMK Negeri 1 Tanjung Palas.

\section{METODE PELAKSANAAN}

Pembelajaran berbasis proyek dengan metode blended learning merupakan salah satu metode pembelajaran yang telah dilaksanakan oleh penulis dan memiliki dampak positif terhadap kegiatan pembelajaran dimasa pandemi Covid-19. Best Practice dilaksanakan pada semester Genap tahun ajaran 2020/2021 mulai bulan Januari sampai Juni 2021 . Tempat pelaksanaan Best Practice adalah SMKN 1 Tanjung Palas, Kec. Tanjung Palas, Kab.Bulungan Provinsi Kalimantan Utara. Bahan yang digunakan untuk Best Practice adalah model Pembelajaran berbasis proyek dengan metode blended learning. Pembelajaran blended learning adalah pembelajaran yang dirancang dengan cara menyatukan proses pembelajaran secara tatap muka dan proses pembelajaran secara online dengan tujuan untuk meningkatkan keaktifan dan kompetensi peserta didik. Pada Pembelajaran daring, penulis menyampaikan materi menggunakan media berupa aplikasi daring yaitu Zoom, Video Pembelajaran, Power Point, PDF, Google Classroom, Youtube dan WhatsApp. Materi yang disampaikan adalah materi yang telah disinkronkan dengan kurikulum industri yaitu Pembibitan Tanaman Kakao, dimana Kompetensi Dasarnya (KD) ada pada mata pelajaran Pembiakan Tanaman kelas X ATPH dan Pembibitan Tanaman kelas XI ATPH. Sedangkan pelaksanaan Praktek secara luring di sekolah dengan tetap mematuhi protokol kesehatan. Siswa dibagi secara berkelompok dengan jadwal luring dilaksanakan secara bergantian. Peserta didik belajar praktek didampingi oleh guru produktif dan Instruktur dari IDUKA. Adanya kurikulum yang lebih sinkron dengan kebutuhan industri ini, maka akan memberikan banyak pembelajaran yang membangkitkan kompetensi peserta didik. Selama pelaksanaan kegiatan, penulis telah mendokumentasikan berupa MoU bersama IDUKA, Instruksi kerja yang berstandar IDUKA, jadwal pembelajaran dan praktek, jurnal praktek peserta didik, absensi, foto kegiatan, materi pelajaran, media pembelajaran, penugasan dan lain-lain. Kesimpulan Best Practice digambarkan dalam bentuk grafik dan tabel agar mempermudah penulis dan orang lain untuk memahaminya.

\section{HASIL DAN PEMBAHASAN}

Hasil

Pelaksanaan pembelajaran berbasis proyek dengan menggunakan metode blended learning dikatakan efektif jika dapat memberikan dorongan peserta didik bisa lebih aktif bertindak dalam pembelajaran. Hal ini dapat dilihat dari hasil observasi selama pembelajaran berlangsung. Ada 3 aspek pengamatan yang diharapkan mewakili dimensi keaktifan belajar peserta didik yaitu : 1. Prestasi belajar (tanggung jawab dalam proses belajar termasuk mengerjakan tugas-tugas yang diberikan), 2. Kerjasama dalam kelompok (kolaborasi, baik antar teman sejawat atau antar peserta didik dan guru), 3. Kehadiran/absensi peserta didik, baik dalam pembelajaran daring maupun luring/praktek.

Tabel 1. Keaktifan Peserta Didik ditinjau dari Aspek Prestasi Belajar

\begin{tabular}{|c|l|c|c|c|c|}
\hline No & \multicolumn{1}{|c|}{ Kompetensi Dasar } & $\begin{array}{c}\text { Jumlah } \\
\text { Siswa }\end{array}$ & $\begin{array}{c}\text { Siswa } \\
\text { Aktif }\end{array}$ & $\begin{array}{c}\text { Siswa } \\
\text { Tidak } \\
\text { Aktif }\end{array}$ & $\begin{array}{c}\text { Persentase } \\
\text { Keaktifan }\end{array}$ \\
\hline 1 & $\begin{array}{l}\text { KD.1 Menerapkan keselamatan dan } \\
\text { kesehatan kerja (K3) }\end{array}$ & 47 & 11 & 36 & $23,40 \%$ \\
\hline 2 & $\begin{array}{l}\text { KD. 2 Menganalisis dan melaksanakan } \\
\text { tempat pesemaian }\end{array}$ & 47 & 19 & 28 & $40,42 \%$ \\
\hline 3 & $\begin{array}{l}\text { KD. 3 Menganalisis dan melaksanakan } \\
\text { penyiapan media pembibitan }\end{array}$ & 47 & 25 & 22 & $53,19 \%$ \\
\hline
\end{tabular}


TEACHING : Jurnal Inovasi Keguruan dan IImu Pendidikan

Vol. 1. No. 3 September 2021 e-ISSN : 2775-7188 | p-ISSN : 2775-717X

\begin{tabular}{|c|l|c|c|c|c|}
\hline 4 & $\begin{array}{l}\text { KD. 4 Menganalisis dan melaksanakan } \\
\text { penyiapan bahan tanam dan Perlakuan } \\
\text { khusus benih }\end{array}$ & 47 & 31 & 16 & $65,96 \%$ \\
\hline 5 & $\begin{array}{l}\text { KD. 5 Menganalisis dan melaksanakan } \\
\text { pembiakan tanaman secara generatif }\end{array}$ & 47 & 38 & 9 & $80,85 \%$ \\
\hline
\end{tabular}

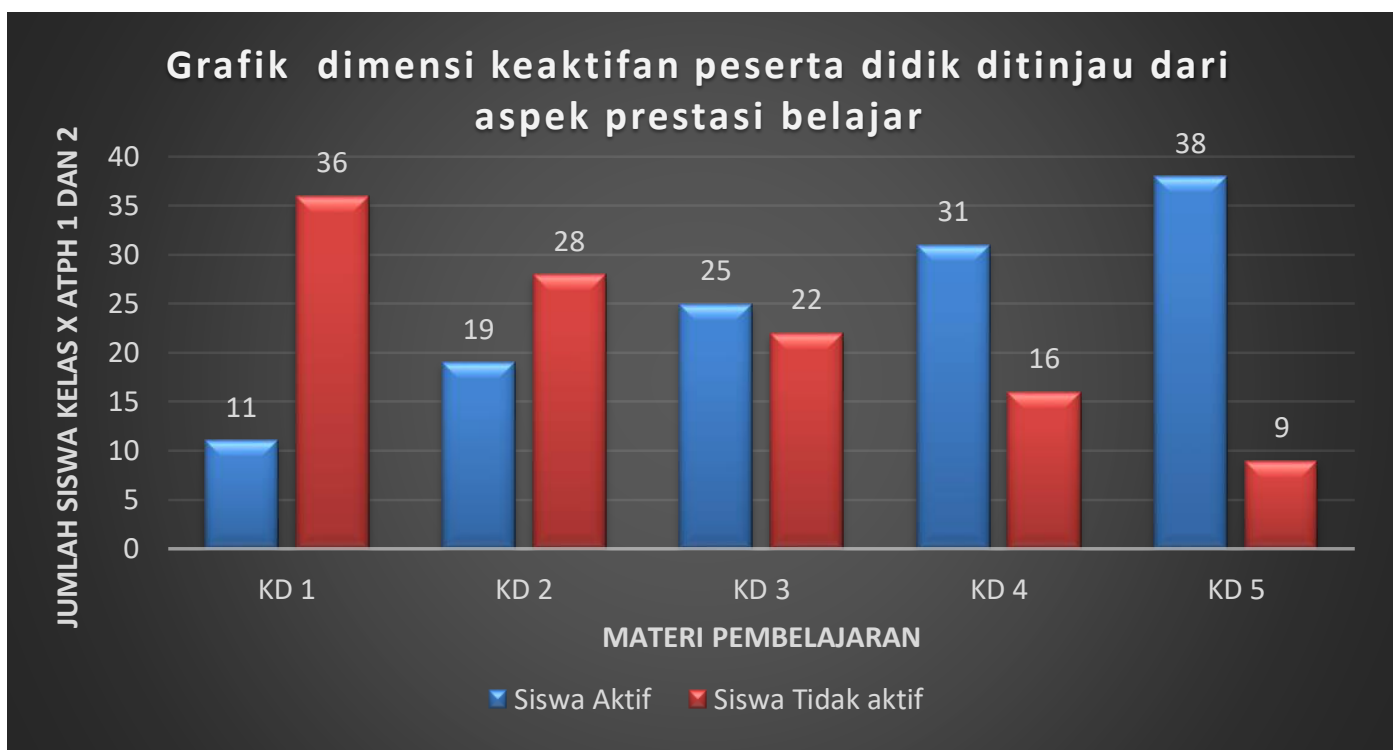

Gambar 1. Grafik Dimensi Keaktifan Peserta Didik ditinjau dari Aspek Prestasi Belajar

Berdasarkan tabel dan gambar grafik 1 di atas dapat dilihat seberapa aktif peserta didik ditinjau dari aspek prestasi belajar. Grafik tersebut menggambarkan keaktifan peserta didik dalam mengerjakan tugas-tugas yag diberikan pada setiap pembelajaran. Pada grafik batang berwarna biru menunjukkan jumlah peserta didik yang aktif dan yang berwarna merah menunjukkan peserta didik yang tidak aktif dalam setiap Kompetensi Dasar (KD). Pada Grafik tersebut menunjukkan adanya peningkatan keaktifan peserta didik pada setiap pembelajaran.

Keaktifan peserta didik ditinjau dari aspek kerjasama dalam kelompok dapat dilihat pada tabel dan gambar grafik 2. Grafik tersebut menggambarkan keaktifan peserta didik dalam berkolaborasi, baik antar peserta didik maupun dengan guru. Dalam kerjasama, anggotaanggota kelompok bekerja bersama, melakukan koordinasi, dan saling membantu satu sama lain. Pada grafik tersebut menunjukkan adanya peningkatan keaktifan peserta didik selama pembelajaran berbasis proyek dilaksanakan. Pada tabel dapat dilihat KD.1 persentase keaktifan $31,91 \%$ terus menerus mengalami peningkatan hingga KD.5 dengan persentase keaktifan sebesar $87,23 \%$.

Tabel 2. Keaktifan Peserta Didik ditinjau dari Aspek Kerjasama dalam Kelompok

\begin{tabular}{|c|l|c|c|c|c|}
\hline No & \multicolumn{1}{|c|}{ Kompetensi Dasar } & $\begin{array}{c}\text { Jumlah } \\
\text { Siswa }\end{array}$ & $\begin{array}{c}\text { Siswa } \\
\text { Aktif }\end{array}$ & $\begin{array}{c}\text { Siswa } \\
\text { Tidak } \\
\text { Aktif }\end{array}$ & $\begin{array}{c}\text { Persentase } \\
\text { Keaktifan }\end{array}$ \\
\hline 1 & $\begin{array}{l}\text { KD.1 Menerapkan keselamatan dan } \\
\text { kesehatan kerja (K3) }\end{array}$ & 47 & 15 & 32 & $31,91 \%$ \\
\hline 2 & $\begin{array}{l}\text { KD. 2 Menganalisis dan melaksanakan } \\
\text { tempat pesemaian }\end{array}$ & 47 & 21 & 26 & $44,68 \%$ \\
\hline 3 & $\begin{array}{l}\text { KD. 3 Menganalisis dan melaksanakan } \\
\text { penyiapan media pembibitan }\end{array}$ & 47 & 30 & 17 & $63,83 \%$ \\
\hline 4 & $\begin{array}{l}\text { KD. 4 Menganalisis dan melaksanakan } \\
\text { penyiapan bahan tanam dan Perlakuan } \\
\text { khusus benih }\end{array}$ & 47 & 39 & 8 & $82,98 \%$ \\
\hline
\end{tabular}


TEACHING : Jurnal Inovasi Keguruan dan IImu Pendidikan

Vol. 1. No. 3 September 2021 e-ISSN : 2775-7188 | p-ISSN : 2775-717X

5 KD. 5 Menganalisis dan melaksanakan pembiakan tanaman secara generatif

47

41

$87,23 \%$

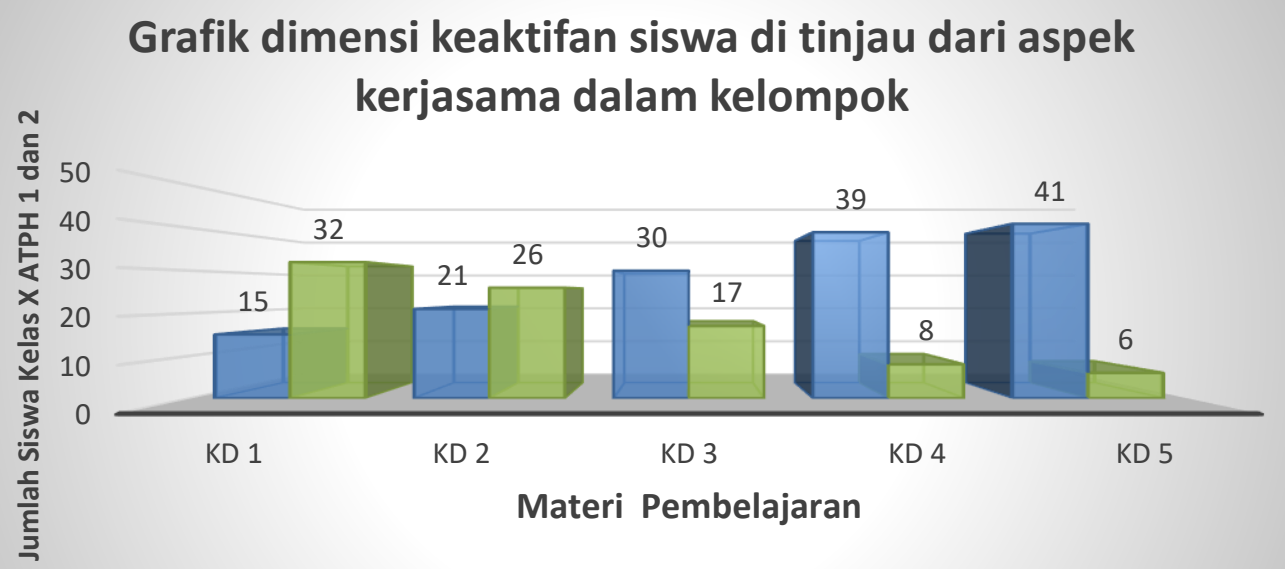

$\square$ Siswa Aktif $\square$ Siswa Tidak Aktif

Gambar 2. Grafik Dimensi Keaktifan Peserta Didik ditinjau dari Kerjasama dalam Kelompok

Keaktifan peserta didik ditinjau dari aspek kehadiran/absensi pada pembelajaran Daring dan luring dapat dilihat pada tabel 3. Pada tabel tersebut digambarkan kehadiran peserta didik untuk pembelajaran daring mengalami fluktuatif, hal ini disebabkan karena beberapa kendala seperti koneksi jaringan internet tempat tinggal peserta didik sulit untuk mengakses internet, selain itu tidak semua siswa memiliki gawai Android dan kuota internet yang menunjang pembelajaran daring. Sedangkan pada pembelajaran luring keaktifan peserta didik mengalami peningkatan mulai dari bulan Januari 65,65\% hingga bulan Juni sebesar 90,90\%. Sehigga metode blended learning sangat efektif dilaksanakan pada masa pandemic dengan tetap memperhatikan protokol kesehatan.

Tabel 3. Kehadiran Peserta Didik pada Pembelajaran Berbasis Proyek dengan Metode Blended Learning

\begin{tabular}{|l|l|c|c|c|c|c|c|}
\hline \multirow{2}{*}{ No } & \multirow{2}{*}{$\begin{array}{c}\text { Model } \\
\text { Pembelajaran }\end{array}$} & $\begin{array}{c}\text { Januari } \\
(\%)\end{array}$ & $\begin{array}{c}\text { Februari } \\
(\%)\end{array}$ & $\begin{array}{c}\text { Maret } \\
(\%)\end{array}$ & $\begin{array}{c}\text { April } \\
(\%)\end{array}$ & $\begin{array}{c}\text { Mei } \\
(\%)\end{array}$ & $\begin{array}{c}\text { Juni } \\
(\%)\end{array}$ \\
\hline 1 & Daring (Teori) & 75,75 & 70,70 & 60,60 & 65,65 & 70,70 & 66,66 \\
\hline 2 & Luring (Praktek) & 65,65 & 68,68 & 75,75 & 84,84 & 87,87 & 90,90 \\
\hline
\end{tabular}

Berdasarkan konsep pelaksanan pembelajaran blended learning, maka tahapan dalam pembelajaran berbasis proyek pada program pembibitan kakao dapat dilihat pada tabel 2 di bawah ini.

Tabel 4. Tahapan Pembelajaran Berbasis Proyek Kompetensi Keahlian ATPH SMKN 1 Tanjung Palas bersama IDUKA PT. Pesona Khatulistiwa Nusantara

\begin{tabular}{|l|l|l|l|l|}
\hline No & Kegiatan & Output & Pelaksanaan & Dokumentasi \\
\hline
\end{tabular}


Vol. 1. No. 3 September 2021 e-ISSN : 2775-7188 | p-ISSN : 2775-717X

\begin{tabular}{|c|c|c|c|c|}
\hline 1 & $\begin{array}{l}\text { Pembuatan } \\
\text { dan } \\
\text { penandatangan } \\
\text { MoU sekolah } \\
\text { dengan } \\
\text { IDUKA }\end{array}$ & $\mathrm{MoU}$ & Luring & 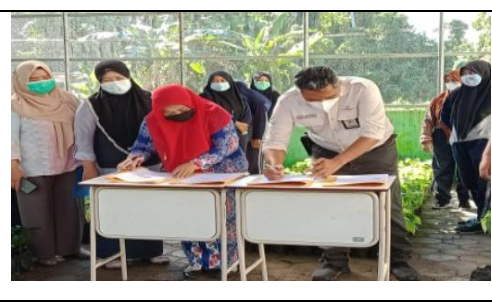 \\
\hline 2 & $\begin{array}{l}\text { Penyelarasan } \\
\text { kurikulum } \\
\text { sekolah } \\
\text { dengan } \\
\text { kurikulum } \\
\text { industri } \\
\end{array}$ & $\begin{array}{l}\text { Dokumen kurikulum } \\
\text { (perangkat PjBL) }\end{array}$ & $\begin{array}{l}\text { Daring dan } \\
\text { Luring }\end{array}$ & Ada dokumen/file \\
\hline 3 & $\begin{array}{l}\text { Koordinasi } \\
\text { pihak sekolah, } \\
\text { IDUKA dan } \\
\text { peserta didik } \\
\text { tentang } \\
\text { pelaksanaan } \\
\text { proyek }\end{array}$ & $\begin{array}{l}\text { Rincian kebutuhan } \\
\text { sarana dan prasarana } \\
\text { proyek }\end{array}$ & $\begin{array}{l}\text { Daring dan } \\
\text { Luring }\end{array}$ & Ada dokumen/file \\
\hline 4 & $\begin{array}{l}\text { Penyusunan } \\
\text { jadwal } \\
\text { pembelajaran } \\
\text { berbasis } \\
\text { proyek dengan } \\
\text { Blended } \\
\text { Learning }\end{array}$ & $\begin{array}{l}\text { Jadwal PJJ dan jadwal } \\
\text { praktek }\end{array}$ & $\begin{array}{l}\text { Daring dan } \\
\text { Luring }\end{array}$ & 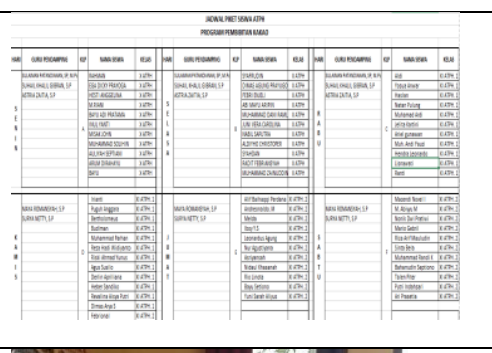 \\
\hline 5 & $\begin{array}{l}\text { Pelaksanaan } \\
\text { PJJ }\end{array}$ & $\begin{array}{l}\text { Foto KBM, absensi, } \\
\text { tugas-tugas dan video }\end{array}$ & $\begin{array}{l}\text { Daring } \\
\text { (menggunakan } \\
\text { aplikasi zoom, } \\
\text { google } \\
\text { classroom, } \\
\text { whats } \\
\text { app,powerpoint, } \\
\text { youtube, dll) }\end{array}$ & \\
\hline 6 & $\begin{array}{l}\text { Pelaksanaan } \\
\text { Praktek }\end{array}$ & $\begin{array}{l}\text { Pembagian kelompok } \\
\text { praktek, Instruksi Kerja, } \\
\text { Foto praktek }\end{array}$ & $\begin{array}{l}\text { Luring (praktek } \\
\text { di lahan } \\
\text { pembibitan } \\
\text { kakao dan } \\
\text { pengumpulan } \\
\text { tugas) }\end{array}$ & 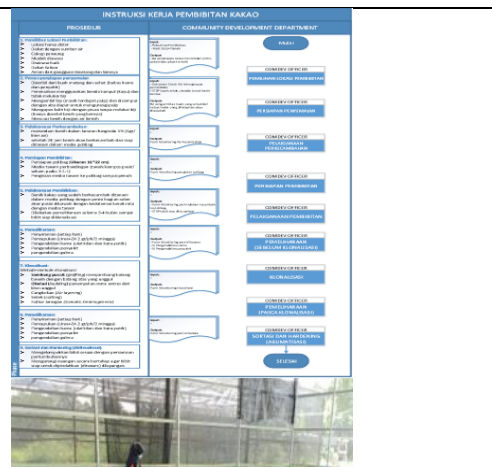 \\
\hline 7 & $\begin{array}{l}\text { Pengisian } \\
\text { Jurnal Praktek }\end{array}$ & $\begin{array}{l}\text { Jurnal praktek yang telah } \\
\text { di paraf oleh guru } \\
\text { pembimbing/pendamping }\end{array}$ & $\begin{array}{l}\text { Masing-masing } \\
\text { peserta didik }\end{array}$ & Ada dokumen jurnal praktik \\
\hline
\end{tabular}




\begin{tabular}{|l|l|l|l|l|}
\hline & $\begin{array}{l}\text { oleh peserta } \\
\text { didik }\end{array}$ & & \\
\hline 8 & $\begin{array}{l}\text { Distribusi } \\
\text { bibit ke lahan } \\
\text { petani binaan }\end{array}$ & Invoice 3100 bibit kakao & $\begin{array}{l}\text { Luring dan } \\
\text { Daring }\end{array}$ & \\
PT. PKN & & & \\
\end{tabular}

\section{Pembahasan}

Saat ini dampak pandemi Covid-19 terhadap dunia Pendidikan sangat terlihat. Bukan hal yang mudah ketika proses pembelajaran mulai dari transfer pengetahuan, keterampilan dan penanaman karakter dilaksanakan secara online. Untuk transfer pengetahuan bisa dimaksimalkan dengan pembelajaran jarak jauh (PJJ), sementara pada komponen keterampilan (skill), dan penanaman pendidikan karakter peserta didik akan terkendala dengan PJJ. Sementara proses pembelajaran harus terus berjalan, guru dituntut kreatif mencari metode pembelajaran yang tepat sehingga dapat memperbaiki proses pembelajaran agar tercipta situasi belajar yang kondusif, motivatif dan ekploratif pada kemampuan belajar peserta didik. Jika hal ini tidak segera dilakukan maka akan berdampak kepada keaktifan peserta didik.

Keaktifan merupakan peran serta seseorang pada saat mengikuti KBM, artinya keikutsertaan siswa untuk berinteraksi antara guru dengan siswa maupun antar siswa dalam KBM. Melvin L. Silberman dalam Hayati (2021) mengatakan saat belajar aktif, para siswa melakukan banyak kegiatan. Mereka menggunakan otak untuk mempelajari ide-ide, memecahkan masalah dan menerapkan apa yang mereka pelajari. Pembelajaran aktif dimaksudkan untuk mengoptimalkan penggunaan semua potensi yang dimiliki oleh anak didik, sehingga semua anak didik dapat mencapai hasil belajar yang memuaskan. Pembelajaran yang menuntut keterlibatan siswa ini sesuai dengan Kurikulum yang berlaku pada negara Indonesia yaitu menggunakan kurikulum 2013 revisi yang menekankan pada peran aktif siswa dan guru sebagai fasilitator dalam proses pembelajaran (Kurniasih \& Sari, 2014).

Guru harus lebih bijak dalam menentukan sebuah metode atau model pembelajaran yang tepat dalam pembelajaran, sehingga proses pembelajaran akan menjadi lebih efektif. Salah satu model pembelajaran yang dapat meningkatkan keaktifan peserta didik yaitu pembelajaran berbasis proyek dengan metode blended learning. Pembelajaran berbasis proyek ini telah dilaksanakan sejak awal semester genap tahun pembelajaran 2020/2021 pada kompetensi keahlian Agribisnis Tanaman Pangan dan Hortikultura bekerjasaa dengan IDUKA PT. Pesona Khatulistiwa Nusantara pada Program Pembibitan Kakao. Pembelajaran berbasis proyek adalah model pembelajaran dengan kegiatan proyek. Pembelajaran berbasis proyek tidak hanya melibatkan peserta didik secara aktif dalam mengembangkan proses berpikir tetapi juga melibatkan peserta didik untuk belajar secara langsung.

Pada pembelajaran berbasis proyek peserta didik belajar lebih baik dan mereka lebih aktif bertindak dalam pembelajaran. Hal ini menjadikan peserta didik aktif menyelesaikan masalah dalam proyek, bukan penerima pasif pengetahuan. Thomas (2000) mendefinisikan isu tentang dampak positif dari pembelajaran berbasis proyek bagi siswa sebagai pengembangan sikap positif terhadap proses belajar mereka, rutinitas pekerjaan, kemampuan pemecahan masalah, dan harga diri. Meskipun siswa mengalami kendala pada tahap awal pelaksanaan pembelajaran berbasis proyek, sebagian besar siswa merasa lebih termotivasi selama dalam pembelajaran berbasis proyek. Karena pembelajaran berbasis proyek memberi kesempatan pada siswa untuk mengimplementasikan kebebasan mereka dalam lingkungan belajar, mereka menghentikan kebiasaan menunggu langkah-demi-langkah pembelajaran berbasis perintah.

Pembelajaran berbasis proyek dengan metode blended learning pada kompetensi keahlian Agribisnis Tanaman Pangan dan Hortikultura (ATPH) SMK Negeri 1 Tanjung Palas, 
merupakan pembelajaran yang memadukan pembelajaran secara tatap muka dan daring, dan memaksimalkan sarana prasarana sekolah sebagai tempat praktek peserta didik dengan kerjasama SMK dan IDUKA. Konsep yang digunakan adalah konsep pembelajaran dengan blended learning dengan desain pembelajaran sesuai tujuan pelaksanaan proyek. Sebelum kegiatan metode blended learning dilaksanakan, selama masa pandemi penulis hanya menggunakan metode pembelajaran daring melalui aplikasi webex, zoom dan classroom, namun seiring berjalannya waktu penulis merasa metode tersebut sudah tidak efektif. Peserta didik mulai merasa bosan dengan belajar dari rumah sehingga berdampak pada menurunnya motivasi dan prestasi belajar. Selain itu kendala utama peserta didik dalam PJJ adalah keterbatasan koneksi jaringan internet dan kuota. Pada akhirnya mereka ke sekolah mengumpulkan tugas-tugas secara luring. Hal ini juga dirasakan peserta didik ketika pelaksanaan praktek pembelajaran dengan PJJ. Penulis memberikan tugas praktek untuk dikerjakan dirumah, namun sebagian besar peserta didik tidak menyelesaikan tugas tersebut. Hal ini karena kurangnya pendampingan dan pengawasan dari guru, selain itu peserta didik kesulitan jika hanya menyaksikan melalui video tanpa peserta didik praktek langsung.

Setelah pelaksanaan metode blended learning, yaitu mengkombinasikan antara pembelajaran online dengan face-to-face (pembelajaran tatap muka). Peserta didik lebih aktif dan termotivasi. Hal ini diperkuat oleh pendapat Garner \& Oke dalam Astuti (2020), bahwa pembelajaran blended learning adalah pembelajaran yang dirancang dengan cara menyatukan proses pembelajaran secara tatap muka dan proses pembelajaran secara online dengan tujuan untuk meningkatkan hasil belajar peserta didik. Tiga komponen penting dalam model pembelajaran Blended Learning yaitu 1) online learning, 2) pembelajaran tatap muka, 3) belajar mandiri. Melalui blended learning dapat menciptakan lingkungan belajar yang positif untuk terjadinya interaksi antara sesama peserta didik, dan peserta didik dengan pendidiknya tanpa dibatasi oleh ruang dan waktu.

Pembelajaran berbasis proyek melalui kerja sama dengan dunia kerja memberikan banyak manfaat diantaranya adanya kesesuaian program yang diajarkan apabila dapat bersinergi dengan kebutuhan industri termasuk pengembangan dalam materi ajar yang bisa disesuaikan dengan perkembangan kebutuhan industri. Peserta didik mendapatkan pengalaman praktek pembibitan kakao sesuai stándar perusahaan. Adapun tahapan dalam Pembelajaran berbasis proyek pada program pembibitan kakao dimulai dari pembuatan MoU SMK dan PT. PKN kemudian dilanjutkan dengan penyelarasan kurikulum sekolah dan kurikulum industri. Koordinasi antara pihak sekolah IDUKA dan peserta didik dilaksanakan melalui daring dan luring untuk merencanakan praktek pembelajaran dan mengetahui kesiapan sekolah dalam hal sarana prasarana praktek. Selanjutnya Guru menyusun jadwal pembelajaran teori dan praktek dengan menggunakan metode blended learning. Pada pelaksanaan pembelajaran berbasis proyek secara daring, peserta didik berada di rumah masing-masing selama mengikuti teori pembelajaran pada jadwal daring dengan menggunakan aplikasi zoom, google classroom, WhatsApp, Power Point, PDF dan Youtube. Sedangkan praktek yang dilaksanakan secara luring dengan membatasi jumlah peserta didik yang hadir melaui pembagian kelompok. Jadwal luring dilaksanakan secara bergantian antar kelompok. Pelaksanaan praktek ini, sesekali akan dihadiri oleh Instruktur dari IDUKA dan didampingi guru produktif ATPH.

Pada awal pelaksanaan praktek di semester genap terdapat keengganan peserta didik kelas X ATPH belajar dalam berkelompok dan melakukan interaksi yang intensif sesama anggota kelompok. Juga terasa sulit membangun interaksi antara siswa dengan guru. Hal ini dikarenakan selama semester ganjil, pembelajaran hanya dilakukan melalui daring. Seiring berlangsungnya pembelajaran berbasis proyek ini, ketertarikan siswa semakin berkembang dan kerja sama antar siswa dalam kelompok semakin tumbuh. Hal ini disebabkan karena terdapat saling ketergantungan antar siswa dalam menyelesaikan kegiatan praktek pembibitan kakao. Begitu juga untuk absensi/kehadiran peserta didik lebih meningkat selama pembelajaran praktek. 
Pembelajaran berbasis proyek juga efektif ditinjau dari prestasi belajar. Hal ini dikarenakan terdapat langkah pembelajaran berbasis proyek yang dapat memfasilitasi siswa dalam memahami materi. Pada langkah penyelesaian proyek, informasi yang telah siswa dapatkan selama kegiatan pembelajaran dapat diterapkan siswa untuk menganalisis dan mengkaji proyek yang telah dilakukan. Hal ini sesuai dengan yang dikemukakan oleh Garber dalam Widjajanti \& Azizah (2019) bahwa prestasi mengacu pada keberhasilan individu dalam memperoleh informasi, terutama berkenaan dengan kemajuan akademis. Selain itu, pada lembar kerja siswa (LKS) telah disediakan kegiatan-kegiatan untuk siswa dalam memahami materi dan mengolah informasi. Hal ini tentunya membawa dampak yang positif terhadap prestasi belajar siswa. Untuk itu pembelajaran berbasis proyek dengan metode blended learning pada kompetensi keahlian Agribisnis Tanaman Pangan dan Hortikultura (ATPH), dapat dijadikan sebagai salah satu solusi peningkatan prestasi belajar dan keaktifan peserta didik dalam pembelajaran SMK di masa pandemic covid 19. Tentunya dalam pelaksanaan tetap menjaga protokol kesehatan dengan pembatasan aktifitas, pembelajaran secara tatap muka, dan memaksimalkan waktu untuk pelaksanaan pembelajaran praktek dengan melibatkan IDUKA di sekolah.

\section{KESIMPULAN}

Berdasarkan hasil pelaksanaan best practice dalam pembelajaran di kelas X Agribisnis Tanaman Pangan dan Hortikultura, maka dapat disimpulkan sebagai berikut :

1. Pembelajaran berbasis proyek dengan metode blended learning mampu meningkatkan keaktifan peserta didik ditinjau dari aspek prestasi belajar. Hal ini dapat dilihat dari keaktifan siswa dalam mengerjakan tugas-tugas yang diberikan, pada KD.1 persentase keaktifan $23,40 \%$ terus menerus mengalami peningkatan hingga KD.5 dengan persentase keaktifan sebesar $80,85 \%$. Dengan metode blended learning dapat menciptakan suasana pembelajaran yang tidak membosankan, karena selain belajar daring, peserta didik juga bisa bertatap muka dan berinteraksi dengan teman dan guru saat praktek. Sehingga materi yang kurang jelas bisa didiskusikan secara langsung.

2. Pembelajaran berbasis proyek dengan metode blended learning mampu meningkatkan keaktifan peserta didik ditinjau dari aspek kerjasama dalam kelompok. Pada awal pelaksanaan praktek di semester genap terdapat keengganan peserta didik kelas X ATPH belajar dalam berkelompok dan melakukan interaksi yang intensif sesama anggota kelompok. Hal ini tampak dari presentase keaktifan peserta didik pada KD. 1 hanya 31,91\% . Seiring berlangsungnya pembelajaran berbasis proyek ini, ketertarikan siswa semakin berkembang dan kerja sama antar siswa dalam kelompok semakin tumbuh dilihat dari peningkatan keaktifan peserta didik pada KD.5 mencapai 87,23\%.

3. Keaktifan peserta didik ditinjau dari aspek kehadiran/absensi juga mengalami peningkatan sejak penerapan pembelajaran dengan metode blended learning. Pada pembelajaran luring keaktifan peserta didik mengalami peningkatan mulai dari bulan Januari 65,65\% hingga bulan Juni sebesar 90,90\%.

Pembelajaran berbasis proyek yang di laksanakan oleh siswa ATPH merupakan salah satu bentuk kerjasama dengan PT. Pesona Khatulistiwa Nusantara (PKN) melalui pemesanan bibit Kakao di SMK untuk didistribusi ke lahan petani binaan PT. PKN. Dengan rancangan kurikulum yang dikembangkan sekolah dengan IDUKA, dinilai dapat meningkatkan kompetensi guru dan peserta didik, mendorong semangat dan keaktifan peserta didik dalam proses belajar, mengembangkan kewirausahaan sekolah berstandar industri serta meningkatkan presentase kelulusan yang diserap oleh IDUKA. Pada akhirnya penulis menyarankan agar sekolah lebih mengembangkan kerjasama dengan IDUKA baik dalam program penyelarasan kurikulum, program magang guru dan peserta didik serta rekruitment kelulusan. 


\section{DAFTAR PUSTAKA}

Astuti, A.N Fajar (2020). Pengembangan Model Praktek kerja Industri (Prakerin) Berbasis Integrited Blended Learning Unit Produksi (IBL UP) SMK Pascapandemi Covid-19. Seminar Nasional PascaSarjana 2020: ISSN :26866404

Balwi, Muhammad Assegaf.2020. Kendala Guru dalam Proses Pembelajaran Online Selama Masa Pandemi Ditinjau dari Kemampuan Information Technology (IT). Guru Muhammad Assegaf Balwi. Jurnal Pendidikan Lintang Songo 3(2)-38-45.

Hayati, Yuniar (2021). Pembelajaran Daring Bervariasi di Masa Covid-19 Untuk Meningkatkan Keaktifan Peserta Didik SMPN 4 Mataram. Jurnal Inovasi Keguruan dan Ilmu Pendidikan. Vo.1.No.1

Kurniasih, I \& Sari. (2014). Implementasi kurikulum konsep \& penerapan. Surabaya: Kata Pena.

Marbun, Purim. 2020. "Desain Pembelajaran Online Pada Era dan Pasca Covid-19". Csrid Journal 12 (12):129-42.

Thomas, J. W. (2000). A review of research on project-based learning. The Autodesk Foundation. https://tecfa.unige.ch/proj/eteach-net/Thomas_researchreview_PBL.pdf

Undang-Undang Republik Indonesia Nomor 20 Tahun 2003 Tentang Sistem Pendidikan Nasional

Peraturan Menteri Pendidikan dan Kebudayaan Nomor 22 Tahun 2016 Tentang Standar Proses Pendidikan Dasar dan menengah

Widjajanti, D.B \& Azizah, I.N (2019). Keefektifan Pembelajaran Berbasis Proyek Ditinjau dari Prestasi Belajar, Kemampuan Berpikir Kritis dan Kepercayaan Diri Siswa. Jurnal Riset Pendidikan Matematika 6 (2) : 233-243 